\title{
Taiteilijan resepti
}

Kuinka taiteilijaidentiteetti muodostuu ja

miten sen kanssa eletään?

\section{VehkaKurjenmiekka}

Vuonna 2016 keräsin Pauli Rautiaisen tekijänoikeustulojen merkitystä selvittävän osahankkeen puitteissa kyselyaineiston kolmen eri alan taiteilijoilta. Tarkoituksena oli selvittää tekijänoikeustulojen merkitystä taiteilijoille sekä taloudellisessa että periaatteellisessa mielessä. Samalla kysyimme kysymyksiä taiteilijoiden suhteesta taiteilija- ja tekijänoikeusjärjestöihin, tekijänoikeuksien ja taiteen merkityksestä sekä siitä, millaisia ongelmia taiteilijat nykyisissä tekijänoikeusjärjestelmissä näkivät. Lähetimme lomakkeen 1385 taiteilijalle, joista kyselyyn osallistui kaikkiaan 256. Taiteilijat edustivat sanataiteen, kuvataiteen ja säveltaiteen eri aloja.

Kyselylomakeaineiston tueksi toteutin kevättalvella 2017 kaksitoista taiteilijahaastattelua, joissa haastattelin lomakkeen täyttäneitä ja jatkotutkimukseen halukkuutensa ilmaisseita taiteilijoita. Haastateltavien valinnassa pyrin siihen, että taiteilijat edustaisivat mahdollisimman tasaisesti eri sukupuolia, tulo- ja ikäluokkia sekä taiteenlajeja. Lomakeaineistoa ja haastatteluja läpikäydessäni kiinnitin huomiota siihen, että taiteilijat puhuivat paljon myös siitä, miten he identifioivat itsensä taiteilijana ja millaiset asiat ylläpitävät taiteilijaidentiteettiä ja saavat jatkamaan alan (koetusta) epävarmuudesta huolimatta.

Taiteilijaidentiteettiin ja taiteilijana elämiseen keskittyen haastattelin syksyllä 2019 uudelleen osaa aiemmin haastatelluista taiteilijoista ja lisäksi kolmea aiemmin haastattelematonta, mutta lomakkeen jo vuonna 2016 täyttänyttä taiteilijaa. Lisäksi pyysin haastateltuja täyttämään uudelleen myös aiemmin tutkimuksessa käytetyn kyselylomakkeen. Kaikkiaan haastatteluja kertyi tutkimusprojektin aikana 21 kappaletta.

Taiteilijaidentiteettiä ja sen muodostumista on Suomessa tutkittu aiemminkin 2000-luvulla. Muun muassa Anna Logrén on tutkinut (kuva)taiteilijapuheen moniäänisyyttä, Susanna Hyvärinen on tutkinut teatteritaidetta edustavien taiteilijoiden taiteilijaidentiteettiä pro gradu -tutkielmassaan ja Atte Oksanen on tutkinut taiteilijan minuutta jo 
hieman vanhemmassa sosiaalipsykologin lisensiaatintutkielmassaan. ${ }^{1}$ Aiemmissa suomalaisissa tutkimuksissa keskiössä ovat olleet muun muassa teatteritaide, tanssitaide ja kuvataide. Lisäksi Kulttuuripolitiikan tutkimuskeskus Cupore on kerännyt taiteilijoiden kokemuksia muun muassa kutsumuksestaja taiteen tekemisestä Taiteen ja kulttuurin barometriin vuosina 2015-2018. Aiemmista kansainvälisistä tutkimuksista mainittakoon Jessica Singerin taideopettajien identiteettiä käsittelevä tutkimus vuodelta 2016 ja Alison L. Bainin kanadalaisten kuvataiteilijoiden taiteilijaidentiteettiä käsitellyt tutkimus vuodelta $2005 .{ }^{2}$ Tutkimuksissa on kuitenkin harvemmin kerätty ja kartoitettu kolmen eri taiteenalan kokemuksia ja rakennettu niiden pohjalta kokonaiskuvaa aiheesta yli taiteenrajojen.

Tässä artikkelissa hahmottelen taiteilijoiden kokemuksia taiteilijaksi tulemisesta ja siitä, kuinka taiteilijaelämästä selvitään. Artikkelin tavoitteena on yhtäältä antaa ääni taiteilijoille ja etsiä sellaisia teemoja piirteitä, jotka yhdistävät taiteilijoiden kokemuksia erilaisista taiteenaloista riippumatta. Toisaalta nostan esille myös joitakin sellaisia piirteitä,jotka ovat ominaisia esimerkiksi vain sanataiteelle tai kuvataiteelle. Lisäksi esittelen haastattelujen pohjalta esille nousseen ajatuksen taiteilijaksi ryhtymisestä eräänlaisena"uskon loikkana”, jonka pohjalle identiteetti lopulta rakentuu. Artikkelia luettaessa on hyvä muistaa, että lähtökohtaisesti jo "taiteilijuus", kuka tai mikä on "taiteilija", on vaikeasti rajattavissa ja määriteltävissä, ja haastateltavatkin kokevat sen merkityksen eri tavoin. Tätä artikkelia varten kerätyssä kyselyaineisto- ja haastattelututkimuksessa rajauksena käytettiin taiteilijan kuulumista johonkin kuva-, sanatai säveltaiteen taiteilija- tai tekijänoikeusjärjestöistä.

\section{Taiteilijan tausta}

Usein taiteilijat kokivat tunteneensa vetoa taiteeseen jo lapsuudessaan tai nuoruudessaan. Kiinnostus taidetta kohtaan oli usein ollut myös erottava tekijä esimerkiksi perheen tai muiden samanikäisten välillä. Taiteilija ei ollut välttämättä kokenut perheensä ymmärtävän rakkauttaan lukemiseen ja kirjoittamiseen tai saaneensa tukea haaveilleen

1 Logrén 2015, Hyvärinen 2017, Oksanen 2004.

2 Singer 2016, Bain 2005. 
kuvataiteilijan työstä. Sen sijaan musiikkiharrastusta oli usein pienestä pitäen tuettu ja siihen on kannustettu. Usein sana- ja kuvataiteilijoiden lapsuusmuistoissa toistui narratiivi "duunariperheestä", jossa perheessä ei ollut aiemmin ollut taiteilijoita. Säveltaiteilijoilla tällaisia kokemuksia ei noussut esiin läheskään yhtä usein.

17 Heti kun mä opin lukemaan, niin mä luin jostain syystä taiteilijoiden elämäkertoja. Ja opettelin piirtämään hirveen hyvin, vaikkei musta maalaria sitten kuitenkaan tullut. Niin se lähti jo lapsuudesta. Toki kodissa ei lausuttu sanaa taide tai kulttuuri ikinä, koska mä oon ihan köyhälistötyöläisperheestä. Perhehän painosti mua opiskelemaan kaupallisia aineita, ja mähän tein siis merkinomin tutkinnon ensinnä. Sit mä pääsin merkonomina taidemuseoon töihin, ja sit yhtäkkiä tajusin, että kyllähän mä näitä varmaan voisin tehdäkin. Ja sit pääsin tänne pyrkimään taideteolliseen, ja sit pääsin sisälle. Mikä hämmästytti mua suurestija mullisti mun elämän.

Kuvataiteilija, 68, mies

17 Olen tosiaan pienestä paikasta, duunarisuvusta,jossa ei ollu kirjoja, eikä keskustelua kirjoista eikä kulttuurista, eikä mitään teatterimatkailua eikämitään sellaista, niin sitse kirjasto, ehkä. Jase et sinne on viety.Se on ollu ihan keskeinen. Että se on ollu vähän sellaista... hortoilua pimeässä, et se on suuri sattuman... koen, et suuri sattuman merkitys siinä. Mut et se että... et vasta lukiossa mä jotenki tulin täysin tietoiseks siitä et se oli tavallaan yksi taidemuoto, mistä mä olin kiinnostunut.

Kirjailija, 41, nainen

17 No siis, mun molemmat vanhemmat lukee paljon, että mulle on aina luettu paljon, ja kyllä he omalla tavallaan ovat siis aina tukeneet mua, myös... kirjailijan ammatissa. Mun perheessä ei oo ammattitaiteilijoita, ketään muuta. Että ehkä se sellainen... tavallaan työn sisällön tuki, että se tulee sitten kollegoilta, selvästi. Mut että... aina mua on kannustettu, ja kyllä tuettu tässäkin, että kunjäin vapaaks kirjailijaks, niin mun vanhemmat ihan siis onnitteli mua siitä, että kyllä ne tietää, että se on se mitä mä haluan tehdä.

Kirjailija, 38, muunsukupuolinen 
Toisinaan lapsuuden perheessä oltiin myös suhtauduttu taiteelliseen työskentelyyn ja taiteilijaksi pyrkimiseen nuivasti. Usein syynä oli ollut ajatus siitä, että taiteellinen työ oli taloudellisesti riskialtista, eikä sitä ollut välttämättä pidetty”oikeana ammattina".

1. No lapsuuden perhe jarrutteli hyvin paljon. Mä oon maaseudulta kotoisin, joten... äiti ja isä tapasivat hyvin pitkään olla sitä mieltä, että koska sä lakkaat piirtämästä ja rupeet tekemään jotain, mistä saa oikeesti rahaa. Mutta sen jälkeen, kun ne näki että poikaa ei mikään pysäytä, ja lisäks että se on nyt pystyny elämään jo aika monta vuotta piirtämisellä, niin eipä nekään oo enää valittaneet.

Sarjakuvataiteilija, 52, mies

\section{Kasvaminen taiteilijaksi}

Taiteilijaidentiteetin muodostumiseen liittyi usein ensimmäisen teoksen julkaisu, esiintyminen suuremmalle yleisölle tai taidealan opinnoista valmistuminen. Erityisesti kirjailijoilla hetki tuntui olevan helpommin määriteltävissä, siinä missä säveltaiteilijoilla ja kuvataiteilijoilla prosessi saattoi olla liukuvampi. Tämä liittyy todennäköisesti siihen, että säveltaiteilijat ja kuvataiteilijat tekivät usein taiteellista työtä pirstaleisemmin kuin kirjailijat ja taiteellinen työ koostui esimerkiksi satunnaisista keikoista ja useissa yhtyeissä soittamisesta tai yksittäisten taulujen maalaamisesta ja pienemmistä näyttelyistä. Raja harrastajan ja ammattilaisen välillä on siis häilyvä. Kyselylomakkeissa (2016ja 2019) suurin osa taiteilijoista kertoi taiteellisen toimintansa alkuvuoden, vaikka he eivät läheskään aina määritelleet tarkemmin sitä, mihin valittu vuosi perustui.

Kuvataiteilijat mainitsivat useimmiten taiteellisen uran lähtökimmokkeena valmistumisen alan opinnoista - tai sitten niiden aloittamisen. Toiseksi yleisin lomakkeissa mainittu uran alkuhetki oli oma näyttely tai osuus yhteisestä näyttelystä. Sen lisäksi esimerkiksi taiteilijajärjestön jäseneksi pääseminen, teos biennaalissa tai ensimmäinen myyty taulu olivat sellaisia virstanpylväitä, joista uran katsottiin lähteneen liikkeelle.

Säveltaiteilijoilla oli suurin hajonta siinä, millaiset asiat merkitsivät heille taiteellisen uran alkua. Yleisimmin esiintyi maininta levytyssopimuksesta tai oman kappaleen julkaisemisesta, mutta myös ensimmäisen yhtyeen perustaminen, ensimmäiset julkiset esiintymiset, musiikilli- 
sesta koulutuksesta valmistuminen ja toimeksiantosuhteet säveltäjinä nousivat esiin. Säveltaiteilijoidenkin enemmistö kertoi taiteellisen työskentelyn alkuvuoden, mutta noin puolet jätti erittelemättä tarkemmin sitä, mikä heille edusti uran alkamista

Sanataiteilijoille alkuhetkeä edusti yleisimmin oman teoksen, erityisesti kirjan, julkaiseminen. Toisinaan mainittiin myös ensimmäinen julkaistu novelli. Toinen toistuva, ammatillisen taiteilijauran käynnistymistä määrittävä hetki oli ensimmäisen apurahan saaminen. Sanataiteilijoista lähes kaikki kykenivät määrittelemään taiteellisen toiminnan alkuvuoden ja suurin osa kertoi myös sen, mitä silloin tapahtui.

7 [...] se prosessi tuntu erilaiselta, ja sit tuli valmiimpaa tekstiä, mä tajusin, et"tää on mun esikoisromaanini!" Mut... sitten se missäkohtaa alkoi olla luontevaa kutsua itseään kirjailijaksi, niin siinä kyllä sitten kesti... ehkä sanotaan sitten toisen romaanin jälkeen, oli semmoinen tietynlainen henkinen kynnys ylitetty. Ja... kyl mulle oli tärkeetä se, et mä pääsin sitten Kirjailijaliitonjäseneksi.

Kirjailija, 39, muunsukupuolinen

7. Ja sit ihan jo siis semmoinenkin, että... apurahahauissa, siel kysytään ammattia, niin miks mä siihen laittasin mitään muuta kuin "kirjailija”. Nykyään se menee ihan rutiinilla, mut sillon alkuun se vaati semmoisen: "Voinks mää nyt tähän...?" "-No laita se nyt siihen kun siihen sä sitä apurahaa haet!"

Kirjailija, 39, muunsukupuolinen

1. Ja sit vuonna 2004, kun mä valmistuin, niin sitten mulle tuli kantaesitys ja kirja sinä vuonna, niin sitten se oli selvää, että se on heti ammatti, ettei tarvinnu pitää sitten sillälailla välivuosia. Et se tietenki vahvisti ehkä sit sitä kirjailijan identiteettiä, tai semmoista... et sitä uskalsi jo ehkä alkaa sanoa- tai itseään tolleen ulkoapäin, että kun julkaisee kirjan, niin vaikka olisin mikä ammatiltaan, niin ruvetaan sanomaan kirjailijaksi. 


\section{Ystävät, kollegat ja yhteisöt taiteilijan tukena}

Tekijänoikeuksien ja tekijänoikeustulojen merkityksen tutkiminen oli alun perin tutkimuskärkenä osahankkeessamme, mutta niiden kautta syntyi luontevasti yhteyksiä taiteilijajärjestöjen merkitykseen taiteilijoille. Yhteisöjen ja järjestöjen merkitys vaihtelee taiteilijakohtaisesti, mutta jo pelkästään tutkimuslomakkeiden pohjalta oli selvää, että suurimmalle osalle taiteilijoista sosiaaliset suhteet tai järjestöt olivat työssä jaksamisen kannalta tärkeitä. Lisäksi taiteilijat saivat usein töitä verkostojensa kautta, konsultoivat toisiaan apurahahakemustensa teossa, antoivat toisilleen neuvoja esimerkiksi kustannussopimusten suhteen, perustivat taidekollektiiveja ja ammensivat inspiraatiota toistensa taiteesta. Taiteilijat viittasivat usein ristiin ystäviin ja kollegoihin, ja heidän sosiaalinen ympäristönsä vaikuttikin muodostuvan siten, että suuri osa ystävistä oli myös taiteilijoita. Olisikin hyvin vaikeaa eritellä sitä, milloin kyse oli taidealalla työskentelevistä tai taidetta tekevistä ystävistä ja milloin muunlaisista tuttavista. Siksi pidättäydyn tekemästä tarkempia jaotteluita tässä artikkelissa.

Taiteilijoille ystävien ja muiden taiteilijoiden tuki tuntui usein olevan hyvin tärkeää, vaikka toisaalta etenkin kuva- ja sanataiteessa taiteen tekeminen nähtiin hyvin yksinäisenä prosessina. Yleisestikin taiteilijan yksinäisyys tuntuu olevan paljon käsitelty teema. Monet kuuluisista taiteilijoista ovat ammentaneet taiteeseensa yksinäisyyden ja ulkopuolisuuden kokemuksista ja siitä on tullut jopa määrittävä osa heidän taidettaan, kuten vaikkapa Edward Hopperin tunnetuissa maalauksissa. ${ }^{3}$ Itsenäisen ja yksinäisen työskentelyn vastapainona sosiaalisten suhteiden ja yhteisöjen merkitys kuitenkin korostuu.

1. Hyvin, hyvin suuri. Ihan oikeestaan aika korvaamaton. Et... kirjottaminen on tosi yksinäistä hommaa, koska siinä ollaan oman pään sisällä jajumitetaan jossa toimist-, omalla kotitoimistolla määkin.

Kirjailija, 39, muunsukupuolinen

3 Hopperin ja muiden taiteilijoiden teoksia ja yksinäisyyttä on käsitellyt muun muassa Olivia Laing esseekokoelmassaan The Lonely City: Adventures in the Art of Being Alone (2016). 
7)

Mäluulen, ettäse liittyy mulla myös tosi paljon siihen, ettäkun tausta on niin... ei-kulttuuri, ei-koulutettu, niin sitten se... kollegoiden...jotenkin... olemassaolo ja ystävyys, siis et must tuntuu, että ei sitä kirjoittamisen... iloja ja... kauhuja kukaan ymmärrä, jos ei itse kirjoita. Mä luulen, että... siinon semmoista vertaisuutta. Mikä liittyy siis siihen, että voidaan puhua mistä tahansa, mutta että se jotenki lohduttaa se [nauraa] että toinen tietää, et mä voin hyvin lyhyesti sanoa, mikä on tilanne, vaikka... suhteessa käsikirjoitukseen. Niin se on siis valtava. Sen lisäksi niin... sehän on tosi myös rikastuttava, että...jailoalisäävä, se ettälukee...ystävien onnistuneita taideteoksia, ja sitten saan myös kuulla niiden prosesseista tai seuratajotain et miten se syntyy,ja putkahtaa maailmaan.

Kirjailija, 41, nainen

Kokemus yhteisöstä, johon kuulua, oli myös taiteilijan identiteettiä vahvistava tekijä. Esimerkiksi Suomen Säveltäjien tai Kirjailijaliiton jäseneksi pääseminen saattoi edustaa taiteilijalle sellaista rajapyykkiä,jonka myötä kokemus omasta taiteilijuudesta oli todella konkretisoitunut. Kyselylomakkeissakin moni mainitsi juuri järjestön jäsenyyden oman taiteilijuuden määrittäjänä tai sellaisena tekijänä, joka kertoi ammattimaisuudesta ja taiteen laadusta.

Järjestöt voitiin kuitenkin kokea myös etäisiksi. Vaikka taiteilija olisikin kuulunut taiteilijajärjestöihin, yhteys niihin saattoi olla ohut tailähes olematon. Esimerkiksi kuvataiteilijan ainoa yhteys Taidemaalariliittoon saattoi olla alennushintaisten taidetarvikkeiden ostaminen ja Sanaston toiminta oli toisinaan kirjailijalle monilta osin vierasta. Jäsenyys ei ollut tae toiminnan tuntemisesta tai siihen osallistumisesta. Säveltaiteilijoilla oma taiteilijajärjestö koettiin keskimäärin muita taiteenalojaläheisemmäksija sitä pidettiin tärkeänä muun muassa verkostojen luomisen vuoksi.

Mut kuitenkin, siinä on niinku kuitenkin semmosta jonkin verran siinä aktiivisessa ytimessä sellaista aitoa yhteisöllisyyttäja semmosta niinkun tekemisen meininkiä, joka sitoo yhteen. Et se on kyllä mulle tosi tärkeetä. Varsinkin siltä kannalta, ettäjos ois yksin yrittäny saada aikaan jotain juttuja, niin ei varmaan ois silleen pystyny. Et kuitenkin se, että on innostunu porukka ja sit kuitenkin jonkinlaiset järjestölliset raamit, jotka nekin on ehkä kuitenkin jotenkin kotikutosesti pyö- 
ritetyt mut enivei, niin se kuitenkin antaa niinku jonkinlaisia hartioita sitten. Ainakin yrittää tehdä, jos siinä nyt ei aina onnistuta, kun on jonkinlaisia villimpiä hankkeita.

Säveltäjä, 29, mies

1. Ja Sanastoon taas niin... en mä... oikeen ees ymmärrä, että miten se systeemi toimii näin suoraan sanottuna. Että mä oon tosi iloinen, että se on... Niitä ihmisiähän mä en oo koskaan tavannut yhtään, mulla se menee aika paljon ihmisten kautta, se on jossain siellä, se on semmoinen kone, josta sitten tupsahtaa yleensä 10-15 [nauraa] euroa tai pari kymppiä.

Kirjailija, 41, nainen

2

Arvostan sitä [Kirjailijaliittoa] kuitenkin tosi paljon. Niin se on harmi, että se on... että se ei ole ammattiliitto, tavallaan, mutta... En mä koe, et se mun henkinen kotini on. Mutta se semmoinen... kun tapaa niitä ihmisiä vaikka, kun kokoontuu, ja tajuaa, että tunnen täältä kolme. Ja tää on täynnä kirjailijoita, aika iäkkäitä usein niissä tilaisuuksissa, ja sit tajuaa sen, että"niin, tässä on tätä", et se ei oo vaan se oma pieni piiri, et sinne tullaan Lapista junalla sinne kokouksiin, ja... että meitä on kaikkialla [nauraa].

Kirjailija, 41, nainen

Tekijänoikeusjärjestöjen merkitys oli kyselylomakkeiden pohjalta arvioituna suurin säveltaiteilijoille, mikä voi osaltaan johtua siitä, että Teosto on onnistunut luomaan vahvan aseman tekijänoikeustulojen valvojana ja sillä on jo pitkä historia tukenaan. Pääosin sanataiteilijatkin arvostivat Sanastoa, vaikka se koettiinkin yleisesti ottaen etäisemmäksi. Useimmiten lomakkeissa järjestöstä puhuttiin silti positiiviseen sävyyn. Kuvataiteilijoiden suhde Kuvastoon oli poleemisin, sillä suuressa osassa lomakkeista koettiin, ettei järjestöstä ollut ollut juurikaan hyötyä, ja joissakin todettiin jopa, että siitä oli ollut haittaa. Läheskään kaikki kuvataiteilijat eivät edes Kuvastoon kuuluneet. Kuvastokin sai silti monilta kuvataiteilijoilta myös kiitosta ja järjestön työ koettiin tärkeäksi, vaikkei taiteilija olisikaan tekijänoikeuskorvauksia sen kautta juurikaan saanut. 
17 Ja just Kuvasto on tosi hyvä juttu, ne kans ajaa just asioita ja ihanaa et joku ammattimainen henkilö pitää huolta monien ihmisten asioista, niin se on musta tosi hyvääja tärkeetä. Ja muutenkin siis ehdottomasti tommosta kaikkee yhteenliittymistä kannatan.

Kuvataiteilija, 39, nainen

Tekijänoikeusjärjestöjen merkitys taiteilijaidentiteetille konkretisoitui kuitenkin niiden keräämien ja tilittämien tekijäsoikeustulojen sekä tekijänoikeuksien valvonnan kautta. Monelle taiteilijalle pienetkin tekijänoikeustulot olivat periaatteellisesti tärkeitä, sillä ne kertoivat taiteen käyttämisestä. Kirjailijat mainitsivat lomakeaineistossa useaan otteeseen lainauskorvausten merkityksen työn mielekkyydelle ja säveltaiteilijoillekin tekijänoikeustulot kertoivat ennen kaikkea siitä, että heidän musiikkiaan kuunneltiin. Kuvataiteilijoiden ammatti-identiteettiin tekijänoikeustulot sen sijaan eivätjuurikaan vaikuttaneet, sillä suurin osa heistä ei kyselylomakkeissa antamiensa tietojen mukaan saanut sellaisia lainkaan.

17 No ei mul kyl nytten oo mistään oikeestaan. Mä oon joskus saanu jostain Teostosta jonku kympin vuodessa, mutta mun mielestä en oo koskaan saanut Kuvastosta mitään, ja sit mä oon jossain vaiheessa kanssalopettanut hakemasta niitä apurahoja kun ne mun hakemukset ei oo menny läpi.

Kuvataiteilija, 31, nainen

n

Teosto on tavallaan semmonen käytännön pakko suoraan sanottuna, että jos haluaa niitä tekijänoikeuskorvauksia omasta tekemisestään, niin tavallaan aika mahoton nyt kuvitella, että niitä jotenkin itse laskuttais sieltä sun täältä, että siinä mielessähän tavallaan se Teoston asema on täysin perusteltu, että semmonen pulju niinku vaan tarvitaan jotenkin tavallaan hallinnoimaan sitä tekijänoikeuksien taloudellista näkökulmaa, koska muuten siihen sais varmaan tuhottua aikansa ja mielenterveytensä, jos semmosta yrittäs niinku ite lähtee taiteilijajärjestö tekeen. 
On kuitenkin huomattava, että usein silloinkin, kun taiteilijan saamat tekijänoikeustulot olisivat olleet olemattomat tai hyvin pienet, tekijänoikeusjärjestöihin suhtauduttiin kuitenkin melko positiivisesti. Oli tuloja tai ei, niiden työ tekijänoikeuksien valvojana ja vartijana nähtiin tärkeäksi. Tekijänoikeudet olivatkin taiteilijoille lähes järjestäen luovuttamattomia ja ne nähtiin korvaamattoman arvokkaina.

17 Tekijänoikeudet ovat perusoikeus. Laulut ovat lapsiani.

Säveltäjä, 45, nainen

\section{Tulot ja yhteiskunnallinen asema}

Taiteilijoiden suhde taiteellisen toiminnan tuloihin oli usein hyvin ristiriitainen. Pienetkin tulot kertoivat taiteen kiinnostavuudesta ja siitä, että joku on ollut valmis siitä maksamaan. Samaan aikaan ne saatettiin kokea taloudellisesti merkityksettöminä tai toisinaan jopa loukkaavina almuina,"vappunaamarirahoina”. Toisaalta etenkin kuvataiteessa pienet tulot tarkoittivat sitä, ettei rahaa uuden taiteen tekemiseen välttämättä ollut, sillä välineisiin - esimerkiksi maaleihin tai kanvaaseihin - kului merkittävä osa taiteilijoiden saamista tuloista. Myymätön taulu oli siis taiteilijalle myös kannattamaton sijoitus.

Tuloista erityisen paljon tunteita herättivät apurahat ja tekijänoikeustulot, muun muassa lainauskorvaukset.

1. Mut se on polarisoi - se on niin helvetin... [huokaa] polarisoituu se homma, siis nää et mainostaako kustantamo, kiinnostuuko kustantamot - siis ku jotku kustantamot, naistenlehdet ja ne televisiotkin liittyy, siis nää konsernit, yhteen, ja tyyliin nää itse ei kuulu siihen itse hommaan. Ja sit se jotenkin, että... [huokaa liikuttuneen oloisena] Et se huomio... koen et saan ihan tarpeeks huomiota, mutta rahaa voisin ottaa [naurahtaa]. Sit se liittyy tosi paljon just siihen, että... Et ilmeisesti... Joku saa ihan helvetisti - jotkut saa ihan helvetisti niitä, siis tuhansia euroja niitälainauskorvauksia, suurin osa saa tosi vähän.

Kirjailija, 41, nainen

Taiteilijoiden tulojen ajatellaan usein olevan pieniä ja pirstaleisia, ja tätä mielikuvaa myös taiteilijat itse pitivät lomakkeissa ja haastatteluissa 
esillä. Pääosin tutkimusten taiteilijat eivät kuitenkaan olleet erityisen köyhiä, jos kohta eivät erityisen rikkaitakaan. Mikäli taiteilijoiden tuloja tarkastellaan kokonaisuutena, eikä ainoastaan taiteellisesta työskentelystä saatavien tulojen näkökulmasta, taiteilijat asettuivat yleensä pienituloisen ja keskituloisen välimaastoon. Taiteilijoiden taloudellista asemaa on kartoitettu muun muassa Taiteen edistämiskeskuksen Taiteilijan asema -tutkimuksissa, joista viimeisin käsitteli vuotta $2010 .{ }^{4}$ Pauli Rautiaisen artikkeli "Riutuva taiteilija on median hellimä myytti” (2018) ruotii myös taiteilijan koetun taloudellisen aseman ja todellisten tulojen välistä suhdetta. ${ }^{5}$

Vaikka taiteilijoista suuri osa onkin pienituloisia, Rautiaisen mukaan nälkätaiteilijuudesta ei kuitenkaan ole kyse, sillä suurin osa taiteilijoista tulee kuitenkin kohtuullisesti toimeen, jos kohta ei taiteella rikastumaan pääsekään. Pienituloisia taiteilijoista oli kyselylomakkeihin saatujen vastausten perusteella vain $20 \%$ vastaajista. Toisaalta vain hyvin pieni joukko taiteilijoista tuli toimeen taiteellisesta toiminnasta saamillaan tuloilla. ${ }^{6}$ Tulonmuodostuksessa on kuitenkin paljon eroja taiteenlajien välillä ja aihetta olisi syytä tutkia vielä yksityiskohtaisemmin, jotta esimerkiksi kuvataiteen ja säveltaiteen sisäiset tuloerot tulisivat paremmin näkyviksi. Lisäksi on muistettava, että tässä artikkelissa keskiössä ovat kuitenkin taiteilijoiden kokemukset tuloista ja niiden muodostumisesta, ja ne saattavat poiketa joissakin tapauksissa paljon siitä, miltä taidekentän tulonmuodostus tilastojen valossa näyttää.

Yleisesti ottaen voidaan todeta, että taiteellisesta toiminnasta saatavien tai siihen liittyvien tulojen jakautuminen ei tutkimustenkaan mukaan ole tasaista, sillä se perustuu paljolti taiteen kuluttamiseen ja sen tekemistä tukeviin apurahoihin. Taiteilijoiden negatiiviset kokemukset kumpuavatkin usein juuri tästä epätasaisuudesta ja siitä, että tekijänoikeusjärjestelmät sekä apurahojen myöntäminen koetaan epäoikeudenmukaisiksi. Vaikka monet taiteilijat kiittivätkin järjestöjä hyvästä työstä tekijänoikeuksien valvonnassa ja pitivät tuloja toimeentulolleen tärkeinä, ne herättivät myös katkeruutta ja epätoivoa. Samoin oli apu-

4 Rensujeff 2015.

5 Rautiainen 2019.

6 Rautiainen 2019. 
rahojen laita: vaikka ne nähtiin tärkeinä taiteellisen työn tukemisen kannalta, niiden hakemista pidettiin stressaavana ja vaivalloisena. Lisäksi myönteistä apurahapäätöstä saattoi seurata suru siitä, että moni kollega jäi ilman. Apurahojen epätasaista jakautumista ja taiteellisen menestyksen kasautumista kuvataiteilijoiden keskuudessa on tutkinut Laura Lehenkari pro gradu -tutkielmassaan "Taiteilijoiden eriarvoisuus - tutkimus menestyksen kasautumisesta suomalaisten kuvataiteilijoiden keskuudessa 2000-luvulla” (2018). ${ }^{7}$ Tutkimuksessa todettiin, että etenkin kuvataidealalla apurahat kerääntyvät usein pienelle joukolle taiteilijoista ja aiempi menestys ruokkii myös tulevaa menestystä alalla.

Kuvataiteen puolella tulojen epätasaisuus korostui erityisesti. Suurimmalla osalla taiteilijoista oli joko jokin toinen ammatti taiteenteon ohella tai sitten he elivät sosiaalitukien ja apurahojen varassa. Monet kuvataiteilijoista tekivät myös paljon freelancer-töitä. Freelancerina toimiminen koettiin hyvin stressaavaksi, mutta jotkut taiteilijoista mainitsivat sen toisaalta tuovan myös vapautta työskentelyyn ja aikatauluihin.

Sitä tietää, että tunnit on rajattu mitä pystyy työaikana tekemään, niin pystyy ehkä tiristämään siinä ajassa enemmän, mutta se on ehkä isoin ongelma tossa, että oksennustaudin Damokleen miekka riippuu koko ajan vaara, ettäjompikumpi lapsi sairastuu ja sit on pakko olla kotona, niin se on ehkä semmonen vaikee juttu ja sit toisaalta se, että jos on joku kiireellinen juttu, niin ei pysty oikeastaan koskaan venyttämään sitä.

Kuvataiteilija, nainen, 37

Yhteiskunnallisella tasolla taiteilijan asema nähtiin yhtäältä suhteellisen hyvänä ja arvostettuna. Toisaalta osa taiteilijoista koki, että yhteiskunta voisi tukea taidetta enemmän. Erityisesti kuvataiteilijoilla tämä ajatus toistui muita useammin. Haastatelluista taiteilijoista kukaan ei kokenut, että taiteilijuutta pidettäisiin yleisesti ottaen negatiivisena tai hävettävänä.

7 Lehenkari 2018. 
17 Mä sanoisin, että [kirjailijan asema on] aika... korkea. Toki meillä on hirveän vahva...realismin perinne.Joo,ja sitkun itenyton vieläTampereelta, niin siellähän se sitten vasta onkin. Silleen:"kiitti vaan, Väinö Linna!"

Kirjailija, 39, muunsukupuolinen

\section{Taiteen ja sen tekemisen merkitys}

Taiteilijat puhuivat työstään kyselylomakkeissa ja haastatteluissa usein kutsumusammattina. Samanlaisia tuloksia saatiin myös Taiteen edistämiskeskuksen nuorien taiteentekijöiden kokemuksia käsitelleessä tutkimuksessa vuonna 2017. ${ }^{8}$ Ylipäätään taiteeseen liittyi voimakkaita tunteita ja halu tehdä sitä haasteista ja ongelmista huolimatta. Tältä osin tutkimushankkeemme ja Taiteen edistämiskeskuksen tutkimuksen tulokset ovat hyvin yhteneviä. Kutsumusajattelu ja haasteiden kanssa painiskelu näkyvät myös vanhempien taiteilijoiden vastauksissa, joten vaikka Taiteen edistämiskeskuksen vuoden 2017 tutkimus kohdistuikin nuoriin taiteentekijöihin, voidaan todeta, että ilmiö yhdistää jossain määrin kaikkia taiteilijoita. Taiteen yhteiskunnallista merkitystä ja sen itseisarvoa on tutkittu valtavastija siitä keskustellaan sosiaalisessa mediassa ja lehtien palstoilla vuodesta toiseen. Jo yksittäinen internethaku sanoilla"taiteen yhteiskunnallinen merkitys" tuottaa yli puoli miljoonaa tulosta. On siis selvää, että taiteella on merkitystä - mutta millaista?

Taiteilijat puhuivat taiteen tekemisestä usein hyvin intohimoiseen sävyyn. Monet haastatelluista ja kyselyyn vastanneista taiteilijoista puhuivat taiteesta kutsumuksena tai sisäisenä pakkona. Taiteilijan työtä verrattiin toisinaan jopa hulluuteen.

M

Mun on pakko, mulla on vahva sisäinen pakko. Mä oon lapsesta saakka rakastanut tarinoita. Mä olin kyl myös hirvee kusettaja. [naurahtaa] Siis koska... siis tarkoitan sitä että musta oli vaan kiva keksii kaikkee tarinoita ja sit se joskus meni siihen, että mä saatoin joskus selittää kavereille, että mulle on tapahtunu tällaistaja tällaista, kun mitään sellaista oikeesti tapahtunut. Mutta... sieltä se kumpuaa. Joo. Semmonen vahva sisäinen paloja pakko.

Kirjailija, 39, muunsukupuolinen

8 Taiteen ja kulttuurin barometri 2017, 34 . 
1. Se on jonkinlainen sisäinen hulluus. Että tätä on niinku pakko tehdä, niinku mä oon monesti sanonu oppilaillekin että tota et älä tee mitään ellei oo pakko. Että vasta sitten kun on pakko, niin sitten voi tehdä. Et niinku semmonen tekemällä tekeminen, se on ihan tyhjänpäivästä, että pitää olla semmonen pakko. Pitää olla joku semmonen paha möykky sisällä, jota pitää purkaa.

Kuvataiteilija, 68, mies

Taide koettiin lisäksi merkityksekkääksi myös yhteiskunnallisella tasolla. Taiteeseen liitettiin sellaisia arvoja kuin sivistys, luovuus ja mahdollisuus muuttaa maailmaa. Taiteilijat mainitsivat myös, että taiteen keinoin oli mahdollista kuvata tai sanallistaa sellaisia asioita, jotka muutoin olivat vaikeasti lähestyttävissä. Taiteen kautta oli myös mahdollista kommentoida yhteiskunnallisia kysymyksiä ja herättää keskustelua.

Mulle taide on sillain supermerkityksellinen asia, että mun on vaikea ajatella elämää mitenkään ilman taidetta. Mä saan taiteen katsomisesta ihan valtavasti, ja mä en voi kuvitella sellaista maailmaa, jossa ei ois taidetta. Se on niin tärkeää, että taidetta tuetaan. Mä koen, että kaikki meidän sivistys liittyy siihen. Taiteella on mahtava voima tehdä asioita ja muuttaa kaikkea, vaikuttaa ajatteluun ja ihmisten suhteisiin ja ihan kaikkeen. Se on todella merkittävää. Ja taideteoksen merkitys ehkä taiteilijana on siinä, että kun sitä työstää, niin se yksittäinen teos liittyy aina tosi moneen asiaan. Se linkittyy johonkin suurempaan ja siihen laitetaan jotain tosi henkilökohtaisiajuttuja, mutta samalla sillä osallistutaan keskusteluun tai kommentoidaan jotain.

Kuvataiteilija, 39, nainen

Yksi tärkeä motivaattori taiteen tekemiselle oli myös kokemus siitä, että siinä taiteilija on vahvimmillaan. Kirjailijat kokivat usein, että juuri kirjoittamisessa he olivat menestyneet nuoruudesta alkaen, ja siksi päättäneet lähteä tavoittelemaan sitä myös myöhemmin. Taide nähtiin sellaisena työnä, johon oli myös järkevintä suuntautua, koska sillä tavalla taiteilija kykeni parhaiten hyödyntämään omia kykyjään ja vahvuuksiaan. 


\section{Yhteenveto: uskon loikka taiteilijaelämään}

Haastatteluissa ja kyselylomakkeissa nousi usein esiin ajatus taiteilijaksi ryhtymisestä riskinä. Koska taiteilijuus koettiin taloudellisesti epävarmaksi, moni kertoi valinnan taiteilijuuden puolesta vaativan rohkeutta. Tällöin esimerkiksi perheen tai ystävien tuki oli erityisen tärkeää. Samoin kokemukset positiivisesta palautteesta, ensimmäisistä rahallisista palkkioista ja kilpailumenestyksestä toimivat katalyytteinä, jotka saivat harrastajan siirtymään kohti entistä ammattimaisempaa taiteilijuutta.

Moni haastatelluista taiteilijoista kuvaa uransa alkua erityisesti uskaltamisen näkökulmasta. Aluksi oma taito on saattanut tuottaa epäilyksiä ja myös tulevaisuus on pelottanut. Epävarmuus ja halu tehdä taidetta asettuvat näissä kertomuksissa vastakkain, mutta ratkaiseva askel kohti taiteilijuutta on usein ollut päätös ottaa riski seurauksista huolimatta. Tällaista riskinottoa edustavat esimerkiksi osa-aikatyöhön siirtyminen tai irtisanoutuminen muusta työstä taiteellisen työskentelyn mahdollistamiseksi, kuvataidekouluun hakeutuminen tai oman yrityksen perustaminen. Keskeistä on kuitenkin ajatus siitä, että taide on niin tärkeää, että sen vuoksi on järkevää ottaa myös riskejä.

Uskon loikkaa seuraa taiteilijoilla usein kokemus siitä, että taide kannattaa tavalla tai toisella. Usein tämän kokemuksen tarjoavat taiteesta saatavat tulot, joita taiteilija saa vaikkapa ensimmäisestä myydystä taulusta, kustannussopimuksesta tai keikkapalkkiona yhtyeen esiintymisestä. Tulojen ohella tai ehkä jopa niitä enemmän merkitsee kokemus siitä, että joku on kiinnostunut taiteesta ja haluaa siitä maksaa. Taiteesta saatu rahasumma ei olekaan suoraan verrattavissa sen arvoon taiteilijalle, sillä usein pienetkin tulot kannustavat jatkamaan. Taiteellisesta toiminnasta saatavia tuloja tärkeämpää on jollain tasolla taiteen saama huomio ja arvostus.

Ammattitaiteilijuutta tai taiteilijaidentiteettiä eivät tunnukaan ensisijaisesti määrittävän työskentelystä saatavat tulot - vaikka niillä pärjäävät taiteilijat ovatkin asiasta ylpeitä - vaan kokemus siitä, että oma taide on arvokasta ja sille löytyy myös yleisöä. Taiteen itseisarvo ja oman työskentelyn merkitys nousevat taiteilijoilla usein mahdollista leipätyötä tärkeämmiksi: muu työ on käytännössä keino rahoittaa omaa taiteellista kutsumusta. Moni taiteilijoista kokee oman taiteellisen työskentelynsä 
niin arvokkaaksi, että muualta saatava, taiteilijuuden takaamaa elantoa korkeampi tulotaso ei houkuttele, mikäli se johtaisi omaan taiteeseen käytettävän ajan vähenemiseen.

Taiteilijan ura on usein polveileva ja jokainen vuosi voi olla hyvinkin erilainen. Taiteilijat puhuivat paljon siitä, kuinka välillä kaikki sujuu hyvin ja toisinaan koko ajatus taiteen tekemisestä tuntuu vaikealta ja mahdottomalta. Silti harva olisi valmis luopumaan työstään taiteilijana. Taiteilijaidentiteettiäylläpitävät taiteilijayhteisöt, työskentelyn ja töiden saama näkyvyys, taiteesta saatavat tulot ja ennen kaikkea kokemus siitä, että taide tulee nähdyksi, luetuksi tai koetuksi. Usein taiteilijuus on kuitenkin sitä, että uskon loikkia tehdään päivästä toiseen. Taiteilijalle taide on epävarmuuden ja riskien arvoista. 


\section{Kirjallisuus}

BAIN, ALISON L. (2005). Constructing an Artistic Identity. Work Employment and Society, 19.

HIRVI-IJÄS, MARIA, KAIJA RENSUJEFF, SAKARIAS SOKKA \& EERO KOSKI (2017). Taiteen ja kulttuurin barometri. Nuoret taiteentekijät. Kulttuuripolitiikan tutkimuskeskus Cuporen verkkojulkaisuja 47. https://www.cupore.fi/images/ tiedostot/2018/cupore_barometri_2017_final.pdf Katsottu 04.02.2020.

HYVÄRINEN, SUSANNA (2017). Taiteilijaidentiteettija sen monimuotoisuus. Haastattelututkimus viidestä nuoresta taiteilijasta, jotka työskentelevät usean eri taiteenlajin parissa. Helsinki: Helsingin yliopisto.

LAING, OLIVIA (2016). The Lonely City. Adventures in the Art of Being Lonely. (e-kirja). Picador.

LEHENKARI, LAURA (2018). Taiteilijoiden eriarvoisuus. Tutkimus menestyksen kasautumisesta suomalaisten kuvataiteilijoiden keskuudessa 2000-luvulla. Turku: Turun yliopisto.

LOGRÉN, ANNA (2015). Taiteilijapuheen moniäänisyys. Tutkimus mediavälitteisenja (kuva)taiteilijalähtöisen taiteilijapuheen muotoutumisesta. Joensuu: University of Eastern Finland.

OKSANEN, ATTE (2004). Taiteilijan minuus. Luovuuden ja ruumiillisuuden rihmastoja. Tampere: Tampereen yliopisto.

RAUTIAINEN, PAULI (2019). Riutuva taiteilija on median hellimä myytti. Teoksessa Jussila, Veera, Anni Pasanen ja Robert Sundman (toim.): Kilpailevat totuudet. Helsinki: Ylioppilaslehden Kustannus Oy.

RENSUJEFF, KAIJA (2003). Taiteilijan asema. Raportti työstäja tulonmuodostuksesta eri taiteenaloilla. Helsinki: Taiteen keskustoimikunta.

RENSUJEFF, KAIJA (2015). Taiteilijan asema 2010. Helsinki: Taiteen edistämiskeskus.

SINGER, JESSICA (2016). A Work In Progress: Investigating the identity of the artist teacher/freelance artist tutor and its implications for learning throughout the life course. Education in the North, 23. 